\title{
Weight Training Effect of Multi-Poundage System on Bench Press Ability
}

\author{
$\underline{\text { Nolfie Piri }}^{1}$, Ellen Bernadeth Lomboan ${ }^{2}$, Fredrik Alfrets Makadada ${ }^{3}$ \\ 1,2,3Universitas Negeri Manado \\ nolfiepiri1967@gmail.com
}

\begin{abstract}
This study discusses about find out how weight training effect of multi-poundage system on bench press ability in students majoring in coaching education. The research design used in this study refers to the experimental design using "Randomized Control groups pre test and post test desing. This research was conducted at the UNIMA Tondano sports hall. When the study was conducted from June 2019 for eight weeks with a frequency of three meetings per week. The population used in the study were 20 students who were randomly drawn students from the Department of Education FIK UNIMA, which were then divided into groups of 10 students each. The result shows that the research hypothesis which states that: the average bench press ability of the experimental group who were given training for eight weeks was $2.10 \%$ higher than the control group who were not given training. This is proven true by rejecting $\mathrm{HO}$ because $t$ arithmetic is greater than $t$ table and accepting the statistical hypothesis which means the average ability of the experimental group's bench press is better than the control group's bench press ability.
\end{abstract}

Keywords: weigth training effect; multy-poundage system; bench press ability

\section{Introduction}

Sports training must be based on proven training principles based on research results and experience in coaching in the field. Physical training is training that aims to improve physical condition, which is a very important factor that must be possessed by every athlete. Physical training is physical activity carried out in a planned manner, with a view to fostering physical conditions to fulfill tasks in daily life. Brooks stated that: "Physical exercise in principle is to provide physical stress to the body in an orderly, systematic, continuous manner, in such a way that it can improve the ability to do certain jobs". ${ }^{1}$ To improve one of the biomotor components required forms of exercise that are appropriate to the ability of each individual athlete.

Bompa in Ngurah Nala stated that: "training is a complex activity, a performance of athletes that is carried out systematically in a long duration, progressive and tiered individually". ${ }^{2}$ To maintain the physical condition required regular and systematic training by increasing the training load progressively so that the research objectives can be achieved optimally.

The physical condition of the athlete plays a very important role in the achievements of each branch of sport. Without good physical conditions, athletes will not be able to take part in the exercises, let alone compete or compete perfectly. Bompa in Harsono said that "Physical preparation must be considered as one of the main and most important factors needed in training to achieve the highest achievement". ${ }^{3}$ Components of physical conditions can be developed through a programmed training. One popular form of exercise to improve the ability of the physical component is weight training. Weight training is a training done systematically and the load is only used to increase the ability of muscle contractions to achieve certain goals. Training load is actually not directly related to certain sports, but is needed in improving one's physical abilities in order to achieve maximum performance, especially in weight lifting.

\footnotetext{
${ }^{1}$ Broks GA. Exercise Psyology, New Broks GA. Exercise Psyology, New York: John Eiley dan Sons, 1984, p. 378

${ }^{2}$ Bompa IN Ngurah Nala, Studi Fisiologi Olahraga Universitas Udayana, Denpasar, 1998, p.1

${ }^{3}$ Harsono, Opcit, p. 38
} 
Weight training that is done properly and correctly will provide changes in the size of muscle fibers, namely enlarged muscle fibers (hypertrophy), increased joint space, increased muscle coordination and can reduce the possibility of injury. This is supported by Syfruddin's statement that "A moderate weight training program with a lot of repetition (12-20 times) will cause muscle fibers to become large, muscle coordination will be good, joint space to be wider, connective tissue to be stronger." ${ }^{4}$ Muscle strength is a biomotoric component required by all athletes, with levels that differ from one another. This component is enhanced by providing internal and external resistance exercises to the muscles in question.

Forms of weight training to increase muscle strength include: isotonic exercises or isotonic contraction exercises. Isotonic contractions will appear to occur a movement of the limbs caused by changes in muscle lengthening and shortening. Isotonic contractions consist of concentric contractions or eccentric contractions. Concentric contraction is a type of muscle contraction that is common because at the time of shortening, in the muscles there is tension and this tension causes the muscles to become strong, while the eccentric contractions occur when the muscles lengthen and are in tension."

The principle of training to increase muscle strength (weight training) according to Fox in Ngurah Nala, namely: 1) Give excessive burden, 2) Perform progressively throughout the duration of training, 3) Arrange training carefully so that all muscle groups get the right portion and do not overlap , 4) The specifications are in accordance with the sport that they are involved in."

In weight training there are several training methods including: system set, multi-poundage, and pyramid. And these three systems can be used to improve the ability of physical conditions and techniques in weight lifting and weight lifting, especially in bench press.

Bench Press training is a form of physical exercise using weights that can increase physical component elements such as strength, speed, endurance and power. More than that bench press is also one of the force techniques in weight lifting that is contested. To improve bench press skills there are many training methods or training systems that can be used, one of which is a multi-poundage weight training system. The fact that is currently available to students at the F1K PKL Unima Tondano, there are still many shortcomings encountered when doing bench press. A very visible factor in college weightlifting students is that the ability of the arm muscles to lift weights is very minimal. Besides wanting to develop the strength of the arm muscle strength the writer also wants to prove the reliability of the exercise using the multi-poundage system. For this reason, in this study, researchers wanted to focus on this training system in improving bench press ability, with the problem weight training effect of multi-poundage system on bench press ability on Education Department Students in Sports training.

\section{Review of Literature}

\subsection{The Nature of Weight Training}

Weight training is a form of exercise that can improve components of physical conditions such as strength, endurance and speed. A very popular type of exercise in weight lifting and weight lifting is weight training or now known as weight training. In connection with this Harsono said that "Weight Training or weight training if carried out well in addition to improving overall physical ability can also increase strength, speed, power, endurance, which are important factors for athletes". Furthermore Sutrisno said that "Weight training or weight training is an exercise that uses barbells, dumbbells, dumbbells and other weights as a conditioning method to improve performance in the sport of choice."

${ }^{4}$ Syafruddin, Pengantar Ilmu
${ }^{5}$ Mgurah Nala, Lopcit,
p. 53 


\subsection{The Nature of Arm Muscle Strength Training}

There are several definitions of muscle strength expressed by experts, including:

a. Muscle strength is the maximum muscle power that is mobilized to overcome resistance from the outside and from within oneself.

b. Muscle strength is the maximum contraction produced by a muscle or group of muscles.

c. Muscle strength is the ability and muscle to resist resistance in maximum effort.

d. Muscle strength is the body's ability to move maximum power against external resistance.

From many definitions stated that muscle strength is the ability or ability of muscles to resist resistance in the form of a burden so that the body can do activities or movements. Thus, muscle strength is a fundamental physical condition component for every athlete. Trained muscle strength can provide answers to ensure the athlete's appearance in training and even competing.

Harsono said that muscle strength is a very important component because:

a. Strength is the driving force of every physical activity.

b. Strength plays an important role in protecting athletes and the possibility of injury.

c. With muscle strength, athletes will be able to lift heavier weights, athletes can run fast. athletes can throw further and efficiently. athletes can hit harder and can help strengthen joint stability.

$\mathrm{Nala}$ adds that muscle capacity will increase if given maximum or near maximum loading. For training to improve the ability of these muscles to be successful, during training there must be a constant and continuous strain on the muscles by:

a. Increase the intensity or weight of the training load ie the maximum intensity between $90 \%-100 \%$.

b. Increase the number of repetitions or repetition of the burden lifted

c. Increase the number of sets (one series of reps)

d. Increase the frequency or amount of training per week.

Large muscles in the arms include muscular biceps brachil, muscular triceps brachil, and muscular deltoideus. ${ }^{6}$ The location of the muscles in the arm can be seen in the image below.

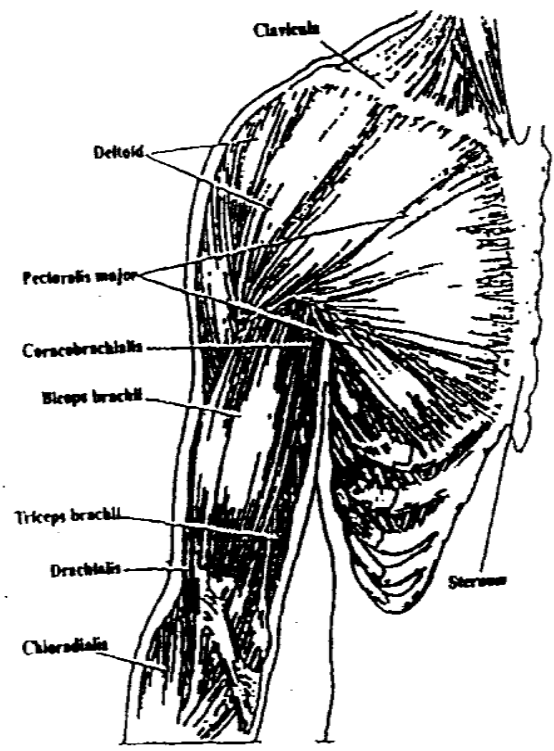

Figure 1. Chest and upper arm muscles of the front

${ }^{6}$ Achmad Damiri, Anatomi Manusia Bagi Pelatih Angkat Besi, FPOK.IKIP Bandung. 1992 pp. 54-59 


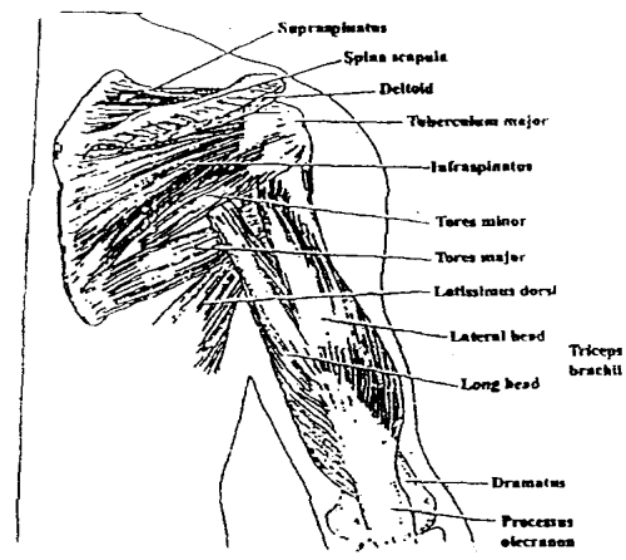

Figure 2. Shoulders and upper back muscles

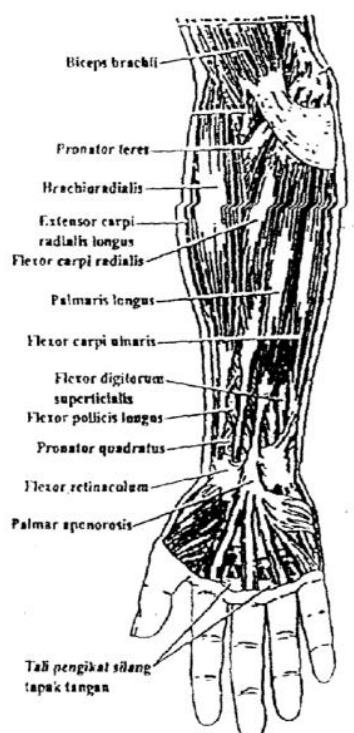

Figure 3. Forearm Muscles

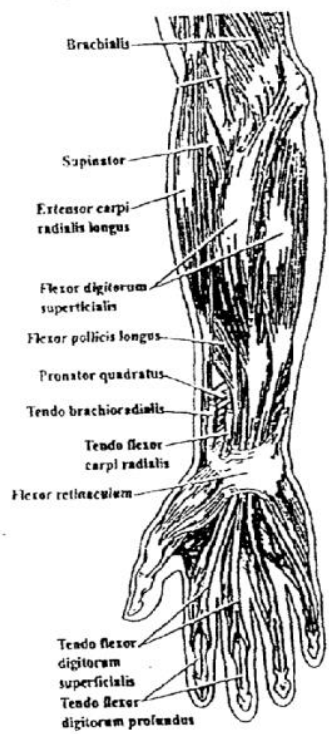

Figure 4. Forearm Muscles Inner Layer

\subsection{Multi Poundage Method}

Multi Poundage Method. MacQueen has introduced what is called the Multi Poundage method. (Morgan and Adamson 1959), The implementation is this: the athlete first performs several repetitions with a heavy burden. Then, if there are signs that fatigue is starting to arise and he can barely lift the heavy burden (for example on the 5th repetition), immediately a friend reduces the weight by removing some of the weight, while the athlete continues to do his strength without resting. If then there are signs that the athlete will fail to continue his generation, his friend will remove some of the weight again and so on until the athlete performs a total of about 20 reps. MacQueen believes that this method is very effective.

\subsection{The Ability of the Bench Press}

The bench press ability is the ability of a person to lift barbell with maximum repetition with sleeping position on the bench bench press. 
Bench press exercises involve the use of barbells and special benches (called bench press benches). Soebroto's translation of Voropev defines that bench press exercises are carried out on benches that are horizontal or tilted.

A similar sentiment was also conveyed by Julien Lasut that: "The ability of a bench press is the ability of a person to lift a barbell with maximum repetition, with a sleeping position on a bench press bench. This exercise is carried out on a horizontal bench or bench that is tilted, specifically to develop the arm extensors, arm extensor muscles, major and minor as well as the front of the deltoid muscle. ${ }^{8}$

The implementation is Litter lying with the back, head shoulder and buttocks (buttocks) attached to the surface and bench bench press horizontally and the two shoes remain on the side of the bench until the completion of the force. The position of both feet is on the side, wide open and the base remains flat on the floor surface. Wide grip distance with over hand grip position supports the barbell, elbows straight. After the barbell is lifted from the support position of both hands straight, then Litter lowers the barbell until it touches the chest then pushes the barbell back up until both hands are straight after that it is returned to the barbell stand. The shape and technique of the bench press movement can be seen in the following figure.
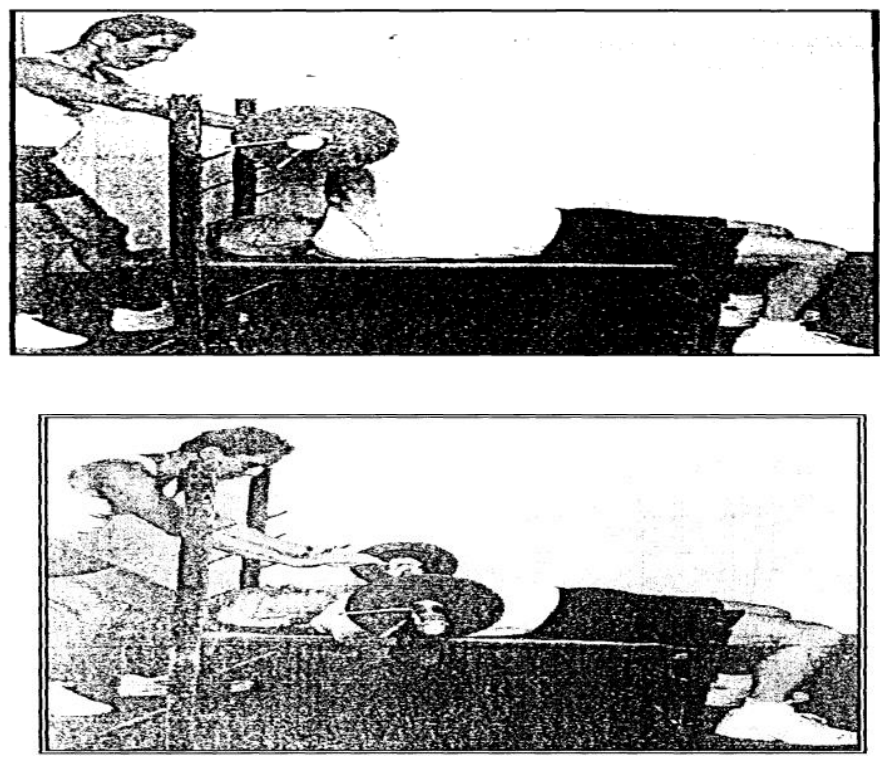

\section{Research Method}

The purpose of operational research is to find out how weight training effect of multi-poundage system on bench press ability in students majoring in coaching education. The research design used in this study refers to the experimental design using "Randomized Control groups pre test and post test desing"9 as for the design can be described as follows:

\footnotetext{
${ }^{7}$ A.N. Vorob'ev, Terjemahan Soebroto. Angkat besi. P.B. PABSI.PT.Enka Parahiyangan, Jakarta, 1989, p. 63 8Julien Lasut, Angkat Besi, Pembibitan Dan Pembinaan, FIK UNIMA, Tondano, 2006, p. 9

${ }_{9}^{9}$ Ary Donal, Cheser Lucy Yacobs And Rasavich Asyhar, Pengantar Penelitian Dalam Pendidikan, Translated by Arief Furchan, Surabaya, 1985, p. 356
} 


\begin{tabular}{|c|c|c|c|}
\hline Group & Pre Test & Treatment & Post Test \\
\hline A & $\mathrm{Y}_{1}$ & $\mathrm{X}$ & $\mathrm{Y}_{2}$ \\
\hline $\mathrm{B}$ & $\mathrm{Y}_{1}$ & - & $\mathrm{Y}_{2}$ \\
\hline
\end{tabular}

Radomized Control Groups Pre Test and Post Desing Test

Information:
A $=$ Experiment Group
$\mathrm{B}=$ Control Group
$\mathrm{Y} 1=$ Initial test for both groups
$\mathrm{Y} 2=$ Final test for both groups
$\mathrm{X}=$ Treatment

This research was conducted at the UNIMA Tondano sports hall. When the study was conducted from June 2019 for eight weeks with a frequency of three meetings per week. The population used in the study were 20 students who were randomly drawn students from the Department of Education FIK UNIMA, which were then divided into groups of 10 students each.

To test the research hypothesis the $t$ test was used in accordance with the research design, namely: Randomized Control Groups Pre-test and Post-test Design, ${ }^{10}$ with the following formula:

$\mathrm{t}=\frac{\bar{X}_{1}-\bar{X}_{2}}{\sqrt[S]{\frac{1}{n_{1}}+\frac{1}{n_{2}}}}$

Where $S^{2}=\frac{\left(n_{1}-1\right) S_{1}^{2}+\left(n_{2}-1\right) S_{2}^{2}}{n_{1}+n_{2}-2}$

Information:

$\bar{X}_{1} \quad$ : Average bench press ability of the experimental group

$\bar{X}_{2} \quad$ : Average control group bench press ability

$\mathrm{S} \quad$ : Standard deviation

n1 : The number of samples of the experimental group

n2 : Number of control group samples

S2 : Standard standard / combined deviation

Accept $\mathrm{H}_{0}$ if $: \mathrm{t} 0 \leq \mathrm{t} 1\left(\alpha: 0,05 ;\right.$ known $\left.=\mathrm{n}_{1}+\mathrm{n}_{2}-2\right)$

Reject $\mathrm{H} 0$ if $\quad: \mathrm{t} 0>\mathrm{t} 1\left(\alpha: 0.05 ;\right.$ known $\left.=\mathrm{n}_{1}+\mathrm{n}_{2}-2\right)$

Before the $t$ test is done, it is tested by analyzing the requirements, namely:

a) Homogeneity Test

b) Normality Test

\section{Discussion}

After measuring the results of the bench press ability test both pre-test data (initial condition) and post-test data (final condition) of the two groups namely the experimental group and the control group, it needs to be processed and analyzed for the purposes of testing the research hypothesis. The data can be seen in the following table.

\footnotetext{
${ }^{10}$ Sudjana, Metode Statistik Edisi IV , Tarsito Bandung, 1986. p. 232
} 
Table 1. Pre-Test and Post-Test Data Experimentation and Control Group

\begin{tabular}{|c|c|c|c|c|c|}
\hline \multicolumn{3}{|c|}{ Experiment Group } & \multicolumn{3}{c|}{ Control Group } \\
\hline No & Pre-test & Post-test & No & Pre-test & Post-test \\
\hline 01 & $41,0 \mathrm{~kg}$ & $50,0 \mathrm{~kg}$ & 01 & $45,5 \mathrm{~kg}$ & $49,0 \mathrm{~kg}$ \\
\hline 02 & 37,5 & 47,5 & 02 & 48,0 & 51,0 \\
\hline 03 & 49,0 & 58,0 & 03 & 38,0 & 40,5 \\
\hline 04 & 50,0 & 61,0 & 04 & 43,5 & 45,5 \\
\hline 05 & 41,5 & 54,0 & 05 & 51,0 & 53,0 \\
\hline 06 & 42,5 & 54,0 & 06 & 41,5 & 44,0 \\
\hline 07 & 42,0 & 55,5 & 07 & 42,0 & 44,0 \\
\hline 08 & 45,0 & 55,5 & 08 & 45,0 & 47,5 \\
\hline 09 & 48,0 & 60,0 & 09 & 50,0 & 54,0 \\
\hline 10 & 50,5 & 61,0 & 10 & 43,5 & 47,0 \\
\hline $\mathrm{n}=10$ & $\Sigma=447$ & $\Sigma=556,5$ & $\mathrm{n}=10$ & $\Sigma=448$ & $\Sigma=475,5$ \\
\hline
\end{tabular}

Table 2. Pre-Test and Post-Test Difference Data Experimentation and Control Group

\begin{tabular}{|c|c|c|c|}
\hline No & Experiment Group & No & Control group \\
\hline 01 & 9,0 & 01 & 3,5 \\
\hline 02 & 10,0 & 02 & 3,0 \\
\hline 03 & 9,0 & 03 & 2,5 \\
\hline 04 & 11,0 & 04 & 2,0 \\
\hline 05 & 12,5 & 05 & 2,0 \\
\hline 06 & 11,5 & 06 & 2,5 \\
\hline 07 & 13,5 & 07 & 2,0 \\
\hline 08 & 10,5 & 08 & 2,5 \\
\hline 09 & 12,0 & 09 & 4,0 \\
\hline 10 & 10,5 & 10 & 3,5 \\
\hline $\mathrm{n}=$ & $\Sigma=109,5$ & $\mathrm{n}=$ & $\Sigma=27,5$ \\
10 & \multirow{2}{*}{$\Sigma$} & 10 & \\
\hline
\end{tabular}

Before entering into the analysis of the research hypothesis testing, testing the requirements as an absolute assumption test needs to be done, which in this study is the normality test and homogeneity test. The data used in the analysis of this assumption test are the initial data (pre-test) of the experimental group and the control group.

Steps to testing normality

a) Hypothesis formulation:

HO: $\mathrm{L} 0<\mathrm{L}=$ Normal Distributed Population

Ha: L0> L = Population Not Normally Distributed

b) Significant level: $\mathrm{p}=\propto 0.05$

c) Test criteria:

Reject $\mathrm{H}_{0}$ if $\mathrm{L}_{0}($ Observation $)>\mathrm{L}\left(\mathrm{L}_{\text {table }}\right)$

d) Test statistics are Liliefors, namely:

- Determine Z1, with the following formula:

$$
Z_{i}=\frac{X_{i}-\bar{X}}{S d}
$$


- Determine $\mathrm{F}\left(\mathrm{Z}_{\mathrm{i}}\right)$ using the standard normal distribution list.

- Determine $S\left(Z_{i}\right)$ using proportions

- Determine the difference value, $F\left(Z_{i}\right)-S\left(Z_{i}\right)$

e) Data computing:

Based on the formula for the liliefors test and by using the initial data (Pre-Test) of the experimental group, a working table can be used with the following calculation.

Known value $\bar{X}=\frac{\Sigma X_{i}}{n}$

$$
\begin{aligned}
& =\frac{447}{10} \\
& =44,7
\end{aligned}
$$

Table 3. Determining Standard Deviations Ex. Experiment

\begin{tabular}{|c|c|c|c|}
\hline No & $\mathrm{X}_{\mathrm{i}}$ & $\mathrm{X}_{\mathrm{i}^{-}} \bar{X}$ & $\left(\mathrm{X}_{\mathrm{i}^{-}} \bar{X}\right)^{2}$ \\
\hline 01 & 37,5 & $-7,2$ & 51,84 \\
\hline 02 & 41,0 & $-3,7$ & 13,69 \\
\hline 03 & 41,5 & $-3,2$ & 10,24 \\
\hline 04 & 42,0 & $-2,7$ & 7,29 \\
\hline 05 & 42,5 & $-2,2$ & 4,84 \\
\hline 06 & 45,0 & 0,3 & 0,09 \\
\hline 07 & 48,0 & 3,3 & 10,89 \\
\hline 08 & 49,0 & 4,3 & 18,49 \\
\hline 09 & 50,0 & 5,3 & 28,09 \\
\hline 10 & 50,5 & 5,8 & 33,64 \\
\hline $\mathrm{n}=10$ & $\Sigma=447$ & - & $\Sigma=179,10$ \\
\hline
\end{tabular}

Standard Deviation $(\mathrm{SD})=\sqrt{\frac{\sum(X i-\bar{X})}{n-1}}$

$$
\begin{aligned}
& =\sqrt{\frac{179,10}{10-1}} \\
& =\sqrt{19,9} \\
& =4,46
\end{aligned}
$$

Table 4. Calculation of the Normality Test Data for the Control Group

\begin{tabular}{|c|c|c|c|c|c|}
\hline No & $\mathrm{X}_{\mathrm{i}}$ & $\mathrm{Z}_{\mathrm{i}}$ & $\mathrm{F}\left(\mathrm{Z}_{\mathrm{i}}\right)$ & $\mathrm{S}\left(\mathrm{Z}_{\mathrm{i}}\right)$ & $\mathrm{F}\left(\mathrm{Z}_{\mathrm{i}}\right)-\mathrm{S}\left(\mathrm{z}_{\mathrm{i}}\right)$ \\
\hline 01 & 37,5 & $-1,61$ & 0,0537 & 0,1000 & 0,0463 \\
\hline 02 & 41,0 & $-0,83$ & 0,2033 & 0,2000 & 0,3330 \\
\hline 03 & 42,0 & $-0,72$ & 0,2358 & 0,3000 & 0,0642 \\
\hline 04 & 42,5 & $-0,60$ & 0,2443 & 0,4000 & 0,1557 \\
\hline 05 & 45,0 & $-0,49$ & 0,3132 & 0,5000 & 0,1868 \\
\hline 06 & 48,0 & 0,07 & 0,5299 & 0,6000 & 0,0701 \\
\hline 0,7 & 49,0 & 0,74 & 0,7704 & 0,7000 & 0,0704 \\
\hline 08 & 50,0 & 0,96 & 0,8315 & 0,8000 & 0,0315 \\
\hline 09 & 50,0 & 1,19 & 0,8830 & 0,9000 & 0,0170 \\
\hline 10 & 50,5 & 1,30 & 0,9032 & 1,0000 & 0,0968 \\
\hline
\end{tabular}


f) Interpretation of the value of $\mathrm{E}$

From the above calculation results obtained $\mathrm{L}$ observation values for the normality test experimental group of $\left(\mathrm{L}_{0}\right)=0.1868$ while the value of $\mathrm{L}$ table $(\mathrm{Ltab})$ at degrees of freedom $(\mathrm{dk}) \mathrm{n}=10$ with a real level $=0.05$ obtained $\mathrm{L}_{\text {table }}$ value $=0.258$. This fact shows that the value of $\mathrm{L} 0$ is smaller than the value of Ltab or in other words the value of $\mathrm{L}_{0}=0.1868<\mathrm{Ltab}=0.258$. Thus $\mathrm{H} 0$ is formulated from the Lilliefors test intended in this study, which reads that a normally distributed population is apparently acceptable. This means that samples taken from the population for the experimental group are normally distributed.

Testing the Normality of the Control Group Data Testing the Normality

a) Hypothesis formulation

$\mathrm{H} 0: \mathrm{L}_{0}<\mathrm{L}=$ The population is normally distributed

Ha: $\mathrm{L}_{0}>\mathrm{L}=$ The population is not normally distributed

b) Significant level: $\mathrm{p}=0.05$

c) Test criteria:

Reject $\mathrm{H}_{0}$ if $\mathrm{L}_{0}$ (Observation) $>\mathrm{L}_{\mathrm{t}}\left(\mathrm{L}_{\text {table }}\right)$

d) Test statistics are Lilliefors, namely:

- Determine $\mathrm{Zi}$ with the following formula:

$$
Z_{i}=\frac{X_{i}-\bar{X}}{S D}
$$

- Determine F ( $\mathrm{Zi})$ using the standard normal distribution list.

- Determine $S(\mathrm{Zi})$ using proportions

$\mathrm{S}\left(\mathrm{Z}_{\mathrm{i}}\right)=\frac{\mathrm{n} \mathrm{Z}_{1}, \mathrm{Z}_{2}, \ldots \ldots \mathrm{Z}_{\mathrm{n}} \text { where }}{\mathrm{n}}<\mathrm{Z}_{\mathrm{i}}$

- Determine the difference value, F ( $\mathrm{Zi})$ - S ( $\mathrm{Zi})$

e) Data computation

Based on the formula of the Lilliefors test formula and by using the initial data (Pre-Test) of the control group, a working table can be used with the following calculation:

$$
\text { Known value } \begin{aligned}
X & =\frac{\Sigma X \bar{i}}{n} \\
& =\frac{448}{10} \\
& =44,8
\end{aligned}
$$

Table 5. Determining Standard Deviations Control Group

\begin{tabular}{|c|c|c|c|}
\hline No & $\mathrm{X}_{\mathrm{i}}$ & $\mathrm{X}_{\mathrm{i}}-\mathrm{X}$ & $\left.\left(\mathrm{X}_{\mathrm{i}}\right)-\mathrm{X}\right)^{2}$ \\
\hline 01 & 38,0 & $-6,8$ & 46,24 \\
\hline 02 & 41,5 & $-3,3$ & 10,89 \\
\hline 03 & 42,0 & $-2,8$ & 7,84 \\
\hline 04 & 43,5 & $-1,3$ & 1,69 \\
\hline 05 & 43,5 & $-1,3$ & 1,69 \\
\hline 06 & 45,0 & 0,2 & 0,04 \\
\hline 07 & 45,5 & 0,7 & 0,49 \\
\hline 08 & 48,0 & 3,2 & 10,24 \\
\hline 09 & 50,0 & 5,2 & 27,04 \\
\hline
\end{tabular}




\begin{tabular}{|c|c|c|c|}
\hline 10 & 51,0 & 6,2 & 38,44 \\
\hline $\mathrm{N}=10$ & $\Sigma=448$ & - & $\Sigma=144,60$ \\
\hline
\end{tabular}

$$
\begin{aligned}
\text { Standard Deviation }(\mathrm{SD}) & =4,01 \sqrt{\frac{\sum X i-\bar{X}}{n-1}} \\
& =\sqrt{\frac{144,60}{10-1}} \\
& =\sqrt{16,10} \\
& =4,01
\end{aligned}
$$

Table 6. Calculation of Control Data Normality Test

\begin{tabular}{|c|c|c|c|c|c|}
\hline No & $\mathrm{X}_{\mathrm{i}}$ & $\mathrm{Z}_{\mathrm{i}}$ & $\mathrm{F}\left(\mathrm{Z}_{\mathrm{i}}\right)$ & $\mathrm{S}\left(\mathrm{Z}_{\mathrm{i}}\right)$ & $\mathrm{F}\left(\mathrm{Z}_{\mathrm{i}}\right)-\mathrm{S}\left(\mathrm{Z}_{\mathrm{i}}\right)$ \\
\hline 01 & 38,0 & $-1,70$ & 0,0446 & 0,1000 & 0,0554 \\
\hline 02 & 41,5 & $-0,82$ & 0,2061 & 0,2000 & 0,0061 \\
\hline 03 & 42,0 & $-0,70$ & 0,2420 & 0,3000 & 0,0580 \\
\hline 04 & 43,5 & $-0,32$ & 0,3745 & 0,4000 & 0,1255 \\
\hline 05 & 43,5 & $-0,32$ & 0,3745 & 0,5000 & 0,1255 \\
\hline 06 & 45,0 & 0,05 & 0,5199 & 0,6000 & 0,0801 \\
\hline 07 & 45,5 & 0,17 & 0,5675 & 0,7000 & 0,1325 \\
\hline 08 & 48,0 & 0,80 & 0,7881 & 0,8000 & 0,0119 \\
\hline 09 & 50,0 & 1,30 & 0,9032 & 0,9000 & 0,0032 \\
\hline 10 & 51,0 & 1,55 & 0,9394 & 1,0000 & 0,0606 \\
\hline
\end{tabular}

f. Value Interpretation of $\mathrm{L}$

From the calculation above, the value of $\mathrm{L}$ observation for the control group normality test is obtained $\left(\mathrm{L}_{0}\right)=0.1325$ while the $\mathrm{L}$ table $(\mathrm{Ltab})$ at the degree of freedom $(\mathrm{dk}) \mathrm{n}=10$ with a real level $=$ 0.05 , the $\mathrm{Ltab}$ value $=0,0258$. This fact shows that the value of $\mathrm{L} 0$ is smaller than the value of $\mathrm{Ltab}$ or in other words the value of $\mathrm{L}_{0}=0.1325<\mathrm{L}_{\mathrm{tab}}=0.258$. Thus the $\mathrm{H} 0$ formulated from the Lilliefors test intended in this study that reads that a normally distributed population is apparently acceptable. This means that samples taken from the population of the experimental group were normally distributed.

Homogeneity testing is intended to see whether the variance of the experimental group is the same as the control group variant.

Homogeneity testing steps

- Hypothesis Formulation

$\mathrm{H} 0: \mathrm{S}^{2}=\mathrm{S} 2^{2}=$ Homogeneous variance

Ha: $\mathrm{S}^{2} \neq \mathrm{S} 2^{2}=$ Variance is not homogeneous

- Significant Level: $\mathrm{p}=\propto 0.05$

- Testing Criteria:

Reject $\mathrm{H}_{0}$ if $\mathrm{F}_{0}\left(\mathrm{~F}_{\text {Observation }}\right)>\mathrm{F}\left(\mathrm{F}_{\text {table }}\right) 1 / 2 \propto(\mathrm{V} 1 . \mathrm{V} 2)$

- Test Statistics is the similarity of two variances, namely:

$\mathrm{F}=\underline{\text { Largest Variance }}$

Smallest Variance

- Computing

From the data from the measurement of the ability of the bench press initial conditions (pre-test) in the experimental group and the control group, the prices are as follows: 


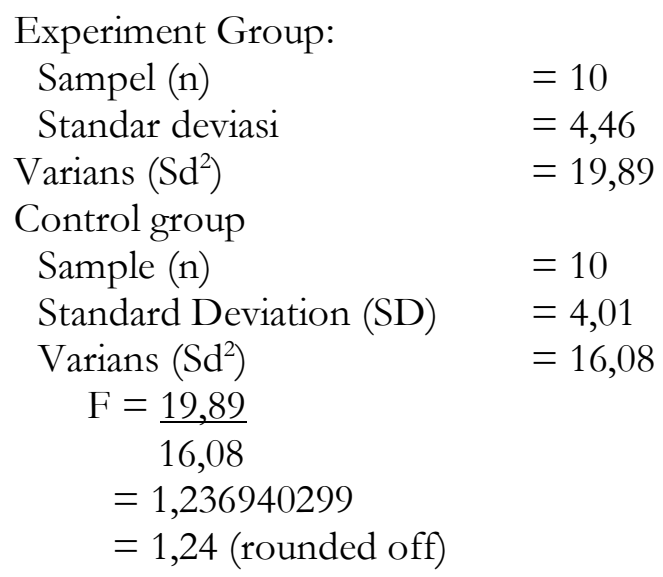

- Interpretation of Value F

From the results of testing the similarity of variance from both the experimental group and the control group, the observation $\mathrm{F}$ value is $\mathrm{F}=1.24$, while the $\mathrm{F}$ table value $=0.05$ with the denominator $\mathrm{dk} 10$ and the numerator $\mathrm{dk} 10$ obtained $\mathrm{F}_{\text {table }}=2.97$. This fact shows that the value of $\mathrm{F}_{0}$ is smaller than the value of $\mathrm{F}_{\text {tab }}$ or in other words the value of $\mathrm{F} 0=1.24<\mathrm{F}_{\text {tab }}=2.97$. Thus $\mathrm{H}_{0}$ is formulated from the variance homogeneity test which reads that the variance is homogeneous in fact accepted. This means that the two sample groups have homogeneous variance in common.

Analysis of Research Hypothesis Testing

Testing steps:

a) Hypothesis formulation

$\mathrm{H}_{0}: \mu_{1}-\mu_{2}$ : There is no effect of multi-pundage system weight training on bench press ability.

$\mathrm{H}_{\mathrm{a}}: \mu_{1} \neq \mu_{2}$ : There is an influence of multi-poundage system weight training on bench press ability.

b) Significant level: $\mathrm{p}=\propto 0,05$

c) Testing criteria

Accepted $\mathrm{H}_{0}$, if $\mathrm{t}_{\mathrm{ob}}<\mathrm{t}_{\mathrm{tab}}(\propto / 2: \mathrm{n} 1+\mathrm{n} 2-2)$

Rejected $\mathrm{H}_{0}$, if $\mathrm{t}_{\mathrm{ob}}>\mathrm{t}_{\mathrm{tab}}(\propto / 2: \mathrm{n} 1+\mathrm{n} 2-2)$

d) Test statistics

$\mathrm{t}=\frac{\bar{X}-\bar{X}}{s \sqrt{1 / n_{1}+1 / n_{2}}}$

where $\mathrm{S}$ is:

$\mathrm{S}=\frac{(n 1-1)_{1}^{2}+(n 2-1) S_{2}^{2}}{n_{1}+n_{2}-2}$

Where:

$\bar{X}_{1}$ : Average bench press difference Experiment Group

$\bar{X}_{2}:$ Average bench press difference Control

$\mathrm{n}$ : Average bench press difference Control

$\mathrm{s}$ : Standard deviation (combined) deviation

d.b : Determined with $(\mathrm{n} 1+\mathrm{n} 2-2)$

e) Computing

From the results of measurements of bench press ability tests with multi-poundage system weight training as an experimental group and a control group as a comparison. Furthermore, by using 
the t-test formula for two different samples and by using the difference data of the pre-test and post-test bench press capabilities of the two experimental and control groups as in table 2 above, the prices needed for the formula formulas are obtained as follows:

\begin{tabular}{ll}
\multicolumn{3}{l}{ Experiment Group } \\
$\mathrm{n} 1 \quad=10$ \\
$\Sigma \mathrm{X}_{1}=109,5$ \\
$\bar{X}_{1} \quad=10,95$ \\
$\mathrm{~S}_{1} \quad=1,46$ \\
$\mathrm{~S}_{1}{ }^{2}$ & $=2,1316$
\end{tabular}

$\begin{array}{ll}\text { Control group } \\ \mathrm{n} 2 \quad=10 \\ \Sigma \mathrm{X}_{2}=27,5 \\ \bar{X}_{2}=2,75 \\ \mathrm{~S}_{2} \quad=0,72 \\ \mathrm{~S}_{2}{ }^{2} & =0,5184\end{array}$

To calculate the value of $\mathrm{t}$ observations, it is preceded by calculating the following combined variance:

$$
\begin{aligned}
\mathrm{t} & =\frac{\bar{X}_{1}-\bar{X}_{2}}{S \sqrt{1 / n_{1}+1 / n_{2}}} \\
\mathrm{t} & =\frac{10,95-2,75}{1,15 \sqrt{1 / 10+1 / 10}} \\
\mathrm{t} & =\frac{8,2}{0,513295634} \\
& =15,94413691 \\
& =15,94 \text { (rounded off) }
\end{aligned}
$$

\section{f) Conclusions}

From the calculation results show that $\mathrm{t}$ observation $\left(\mathrm{t}_{\mathrm{ob}}\right)=15.94$, it turns out to be greater than the value of the critical value in the table for the two-party test of $\left(\mathrm{t}_{\mathrm{tab}}\right)=2.10$. Thus $\mathrm{HO}$ is rejected and $\mathrm{Ha}$ accepts that there is an influence of multi-poundage system weight training on improving bench press ability.

From the results of the presentation of the data it appears that the initial conditions or pre-test before getting a multi-pondage system weight training for the experimental group, as well as in the control group as a comparison it turns out the initial conditions or pre-test results of the two groups did not show differences in terms of bench press ability, this means that the initial conditions of the two groups before being given are the same or homogeneous. While the results of the final condition or post-test of the two groups showed a significant increase in the experimental group while the control group did not show any meaningful.

From the results of calculating the normality of the data with the Lilliefors test both in the experimental group and the control group showed that the two samples were normally distributed. Likewise, the variance homogeneity test in which both groups of samples are shown to show the same variance which in this case are both homogeneous samples. This means that the analysis to prove the research hypotheses was carried out using the parametric statistical analysis approach, which in this study used a t-test statistic of two averages or two different samples.

From the results of the t-test analysis, the average difference between multi-poundage system training on bench press ability in weightlifting turned out to show a significant effect of multi-poundage system training on increasing bench press ability $\left(t=15.94>t_{\text {tab }}=2.10\right)$. These results are consistent with the research hypothesis which states that there is an influence of multi-poundage system training on improving bench press ability. 
The ability of the bench press can apparently be improved through training with a multipoundage system, this means that the training program provided for eight weeks with a frequency of training three times a week is effective enough to improve the bench press ability of the experimental children, in this case the male students majoring in Education Unima's FIK Coaching.

\section{Conclusion}

From the results of data analysis using statistical analysis shows that the research hypothesis which states that: the average bench press ability of the experimental group who were given training for eight weeks was $2.10 \%$ higher than the control group who were not given training. This is proven true by rejecting $\mathrm{H}_{0}$ because $\mathrm{t}$ arithmetic is greater than t table and accepting the statistical hypothesis which means the average ability of the experimental group's bench press is better than the control group's bench press ability.

Thus the conclusion of the research is Bench Press training program with a Multi Poundage system which is given for eight weeks with a frequency of three times a week can improve bench press skills in male students of the Department of Sports Coaching Education.

\section{References}

Achmad Damiri. (1992). Anatomi Manusia Bagi Pelatih Angkat Besi, FPOK.IKIP Bandung.

A.N. Vorob'ev. (1989). Translated by Soebroto. Angkat besi. P.B. PABSI.PT.Enka Parahiyangan, Jakarta.

Ary Donal, Cheser Lucy Yacobs and Rasavich Asyhar. (1985). Pengantar Penelitian Dalam Pendidikan, Translated by Arief Furchan, Surabaya,

Broks GA. (1984). Exercise Psyology, New Broks GA. Exercise Psyology, New York: John Eiley dan Sons.

Bompa in Ngurah Nala. (1998). Studi Fisiologi Olahraga Universitas Udayana, Denpasar.

Fox. E.L. (1979). Sport Physical Weight Resistance Trainning Method And Effect, New York; W.B. Saunders Company

Gabbert. (1987). Physical Education For Children Building The Foundation, New Jersey, 1987

Harsono. (1986). Ilmu Coaching, Pusat Ilmu Olahraga KONI Pusat, Jakarta.

Harsono. (1988). Coaching dan Aspek-Aspek Psikologis dalam Coaching, P2LPTK, Dirjen, pikti, Jakarta.

Julien Lasut. (2006). Angkat Besi, Pembibitan Dan Pembinaan, FIK UNIMA, Tondano.

Ngurah Nala. (1998). Pelatihan Fisik Olahraga, Program Pascasarjana Prodi Fisiologi Olahraga, Universitas Udayana, Denpasar.

Nurhasan. (1986). Tes Dan Pengukuran, depdikbud, universitas terbuka Jakarta.

Sutrisno. (1973). Tuntutan Praktis Latihan, Dirjen Olahraga Depdikbud, Jakarta.

Sudjana. (1986). Metode Statistik Edisi IV, Tarsito Bandung.

Syafruddin. (1992). Pengantar Ilmu Melatih. FPOK IKIP Padang.

Thomas. (1997). R. Beachle B.R. Groves, Latihan Beban, PT. Raja Grafindo Persada Jakarta.

Wayne, L. Westcott. (1999). Translated by Eri Desimarini Nasution, Kembali Bugar setelah lima puluh (Strength Training Past 50). PT. Raja Grafindo Persada. Jakarta. 